\title{
TIMELINE: AN ABBREVIATED HISTORY - THE ORIGINS OF THE BIG EIGHT, AND HOW THEY SHRANK TO FOUR
}

Circa 3400 вС - Systems for inscribing accounting records on clay tablets are developed in Sumeria.

1458 - Benedetto Cotrugli composes his Libro de Larte dela Mercatura in Naples.

1494 - Franciscan friar Luca Pacioli publishes his Summa de arithmetica, geometria, proportioni et proportionalità.

1844 - The Joint Stock Companies Act in England requires railway companies to appoint bookkeepers to keep and maintain their accounts, and to appoint "auditors" from among the shareholders.

1845 - William Welch Deloitte founds the firm that bears his name.

1849 - Samuel Price and Edwin Waterhouse form their London partnership. Frederick Whinney joins the London firm of Harding \& Pullein, formed that year, renamed Whinney Smith \& Whinney in 1894. 
1850 - Mr. Deloitte joins the shareholder/auditors of the Great Western Railway in signing the report, "Audited and approved," on the company's half-yearly accounts for the period ended December 31, 1849.

1854 - William Cooper founds his London firm, to be joined by his brothers as Cooper Brothers \& Co., 1861.

1867 — William Peat establishes his practice in London.

1886 - Charles Haskins begins his New York practice, partnering with Elijah Sells in 1895.

1887 - James Marwick opens in Glasgow, opens in New York in 1896 and partners with Roger Mitchell in 1897, merges with Peat in 1911.

1894 - Arthur Young opens an office in Chicago, joined by his brother Stanley to form Arthur Young \& Company in 1906.

1898 - William Lybrand, Adam and Edward Ross and Robert Montgomery found their firm in Philadelphia.

1900 - George Touche and John Niven form their partnership in London.

1903 - Alwin and Theodore Ernst form their firm in Cleveland.

1913 - Arthur Andersen and Clarence Delaney form their partnership in Chicago, which becomes Arthur Andersen \& Co. in 1918, re-branded as Andersen in 2001.

1924 — Ernst \& Ernst allies with Whinney, Smith \& Whinney.

1933-1934 - The Securities Act and the Securities Exchange Act are passed in the United States. 
1952 - Deloitte, Plender, Griffiths \& Co. in the United Kingdom merges with Haskins \& Sells, globally adopting the name Deloitte Haskins \& Sells in 1978.

1975 - Tohmatsu Aoki \& Co, based in Japan, becomes part of the Touche Ross network.

1979 — Ernst \& Ernst merges with Whinney.

1986 - Peat Marwick merges with Klynveld Main Goerdeler, forming KPMG.

1989 - The shrinkage of the Big Eight begins. Deloitte Haskins $\&$ Sells merges with Touch Ross in the United States and elsewhere. Ernst \& Whinney merges with Arthur Young, re-branded as EY on July 1, 2013.

1998 - Price Waterhouse merges with Coopers \& Lybrand, as PricewaterhouseCoopers, re-branded PwC in 2010.

2002 - Andersen is indicted in Houston on March 14; after trial, the jury's guilty verdict is returned on June 15; Andersen surrenders its professional licenses and ceases to practice as of August 31. 